\title{
PROCJENE UTJECAJA SCENARIJA NISKOUGLJIČNOG RAZVOJA REPUBLIKE HRVATSKE
}

\begin{abstract}
U radu je dan pregled procjene utjecaja scenarija niskougljičnog razvoja Republike Hrvatske do 2030. s pogledom na 2050. godinu. Procijenjeni su utjecaji na energetiku, okoliš, društvo i gospodarstvo. Rezultati su nastali $u$ okviru projekta Ministarstva zaštite okoliša i energetike: Izrada stručnih podloga za Strategiju niskougljičnog razvoja Republike Hrvatske do 2030. s pogledom na 2050. godinu.
\end{abstract}

\section{UVOD}

\section{Globalni kontekst}

Globalna promjena klime danas je jedan od najvećih izazova čovječanstva. Znanstveno je utvrđeno da je uzrok promjene povećana emisija stakleničkih plinova, najviše kao posljedica izgaranja fosilnih goriva, zbog poljoprivrede i sječe tropskih šuma (IPCC, 1990-2014). Zajedničko djelovanje država u cilju sprječavanja globalnih promjena provodi se kroz Okvirnu konvenciju Ujedinjenih naroda o promjeni klime (UNFCCC konvencija). Kyotski protokol uz UNFCCC konvenciju i njegov amandman nisu spriječili globalni porast emisije. Pariškim sporazumom države su se obvezale da će zajedničkim djelovanjem smanjivati emisije stakleničkih plinova s ciljem ograničavanja porasta prosječne globalne temperature do najaviše $2^{\circ} \mathrm{C}$ do kraja stoljeća, a ukoliko bude moguće do $1.5^{\circ} \mathrm{C}$. Ciljevi smanjenja emisija stakleničkih plinova određuju se vlastitim planiranjem, tako da svaka stranka Pariškog sporazuma (ili skupina država) određuje planirani nacionalno utvrđeni doprinos (INDC) do 2030. godine. 
Lin Herenčić, Vladimir Jelavić i Valentina Delija-Ružić: Procjene utjecaja scenarija niskougljičnog razvoja RH Radovi Zavoda za znanstveni rad HAZU Varaždin; br. 29, 2018., str. 361-380

Polazište politike Europske unije (EU) za put prema niskougljičnom gospodarstvu je cilj smanjenja emisija stakleničkih plinova 80-95\% do 2050. godine definirano kroz dokument Plan puta za prijelaz na konkurentno niskougljično gospodarstvo do 2050. godine (European Commission, 2011). U skladu s tim ciljem, a u svrhu utvrđivanja doprinosa EU u okviru Pariškog sporazuma, Europsko vijeće usvojilo je Klimatsko energetski okvir do 2030. godine (European Commission, 2014) kojim postavlja cilj smanjenja emisija stakleničkih plinova za najmanje $40 \%$ do 2030. godine. Također, postavlja se cilj udjela obnovljivih izvora energije (OIE) do 27\% i indikativni cilj smanjenja energetske potrošnje 30\%. U studenom 2016. godine predstavljen je i paket mjera za održavanje konkurentnosti Europske unije uslijed promjena na svjetskim energetskim tržištima i tranzicije na čistu energiju (tzv. Zimski paket) (European Commission, 2016). Zakonodavni prijedlozi o čistoj energiji za sve Europljane obuhvaćaju energetsku učinkovitost, energiju iz obnovljivih izvora, oblikovanje tržišta električne energije, sigurnost opskrbe električnom energijom i pravila upravljanja energetskom unijom. Nadalje, Europska komisija predlaže pomake u području ekološkog dizajna i strategiju za povezanu i automatiziranu mobilnost (European Commission, 2011) te jačanje Europskog sustava za trgovanje emisijama (EU ETS) (European Commission, 2015). Također, važno je istaknuti i EU strategiju za grijanje i hlađenje (European Commission, 2016).

\section{Pregled prethodnih istraživanja}

Europska komisija je u Procjeni učinka Klimatsko-energetskog okvira do 2030. godine (European Commission, 2014) utvrdila između ostalog:

- za provedbu mjera biti će potrebna prosječna godišnja dodatna ulaganja u visini od 38 mlrd. EUR na razini cijele EU u razdoblju od 2011. do 2030. godine, što je oko 1,5\% BDP-a EU. Pritom se ovaj iznos odnosi na razliku od scenarija s mjera u odnosu na referentni scenarij;

- uštede energije će u velikoj mjeri nadoknaditi visinu dodatnih investicija;

- više od pola ovih investicija je potrebno u sektoru kućanstva i usluga;

- težište troškova u energetskom sektoru se pomiče s operativnih troškova (za gorivo) na kapitalne troškove (ulaganja).

Prilikom izrade ove procjene učinaka korišteni su različiti softverski paketi. Svi utjecaji koji se odnose na energetski sustav i važne dijelove gospodarskih utjecaja i rezultirajućih učinaka na emisije $\mathrm{CO}_{2}$ uglavnom se procjenjuju modeliranjem različitih scenarija primjenom PRIMES modela. Ova se analiza proširuje na emisije ostalih stakleničkih plinova i emisije onečišćujućih tvari povezujući PRIMES i GAINS modele zajedno s poveznicama na specijalizirane prometne 
modele (PRIMES-TREMOVE), poljoprivrednim i modelima korištenja zemljišta (CAPRI, GLOBIOM/G4M), koji također dopuštaju pokrivanje utjecaja na emisije iz sektora korištenja zemljišta, promjene u korištenju zemljišta i šumarstvo (LULUCF sektor). Dok modeliranje prometa izravno ulazi u modeliranje energetskog sustava, mogući potencijali smanjenja emisija stakleničkih plinova koji nisu ugljični dioksidi uglavnom se odnose na aktivnosti izvan energetskog sustava, a modelirani su na potpuno dosljedan način (European Commission, 2014).

Paralelno s procjenom učinaka koju izrađuje Europska komisija, provedene su različite dodatne procjene utjecaja politike i mjera u kontekstu klimatsko-energetskog okvira do 2030. godine. Većina dodatnih istraživanja fokusiraju se na različite elemente klimatsko-energetske politike, npr. procjenu implikacija mjera čiji se učinci preklapaju (Flues, Löschel, Lutz, \& Schenker, 2014) (Böhringer, Keller, Bortolamedi, \& Seyffarth, 2016) (del Rio, 2017), energetsku sigurnost (Gracceva \& Zeniewski, 2014) (Criqui \& Mima, 2012), funkcioniranje EU ETS-a (de Parthius \& Trotignon, 2014), optimalne ciljeve za OIE (Knopf, Nahmmacher, \& Schmid, The European renewable energy target for 2030 - An impact assessment of the electricity sector, 2015) (IRENA, 2018) i sl. Neka istraživanja sagledavaju i cijelu energetsko klimatsku politiku EU (Carvalho, 2012) (Knopf, Chen, \& De Cian, Beyond 2020 - strategies and costs for transforming the European energy system, 2013), međutim, s obzirom na opsežnost paketa mjera i međusektorske implikacije to nije jednostavno. Pregovori oko konačnih provedbenih mjera do 2030. godine još su u tijeku, a dodatna istraživanja i procjene utjecaja idu u prilog potvrđivanju nalaza iz Procjene učinaka Klimatsko energetskog okvira do 2030. godine.

Istraživanja vezana za klimatsko-energetsku politiku u Republici Hrvatskoj najčešće su vezana za pojedine segmente klimatsko-energetskog planiranja; razvoj elektroenergetskog sustava (Prebeg, Krajacic, \& Duic, 2016) (Komušanac, Ćosić, \& Duić, 2016), potencijali i integracija OIE (Božičević Vrhovčak, Tomšić, \& Debrecin, 2006) (Krajačić, i dr., 2011), potencijali za uštede energije (Irsag, Pukšec, \& Duić, 2012) (Pukšec, Vad Mathiesen, \& Duić, Potentials for energy savings and long term energy demand of Croatian households sector, 2013) (Pukšec, Krajačić, Lulić, Vad Mathiesen, \& Duić, 2013). Vidljiv je nedostatak međusektorskog i integrativnog planiranja klimatsko-energetskog razvoja, što je tema i doprinos ovog rada. U ovom radu opisan je metodološki pristup i procjena ključnih utjecaja izrađeni prilikom izrade stručnih podloga za Strategiju niskougljičnog razvoja do 2030. godine s pogledom na 2050. godinu. 
Lin Herenčić, Vladimir Jelavić i Valentina Delija-Ružić: Procjene utjecaja scenarija niskougljičnog razvoja RH Radovi Zavoda za znanstveni rad HAZU Varaždin; br. 29, 2018., str. 361-380

\section{METODOLOŠKI PRISTUP I ULAZNI PODACI}

\section{Opis modela}

Kako bi se procijenili svi važni utjecaji scenarija niskougljičnog razvoja Republike Hrvatske primijenjeni su mnogobrojni modeli za simulacije i optimiranje, a razvijen je i integralni model nazvan NUSPCRO (Niskougljično strateško planiranje Hrvatske).

Kao osnova za izradu integriranog modela NUSPCRO na cjelovit i sustavan način korišten je softverski alat LEAP (engl. Long-range Energy Alternatives Planning system) (Heaps, 2016) (Howells, Rogner, Strachan, \& Heaps, 2011). LEAP je integrirani alat za modeliranje koji može biti korišten za analizu energetske politike i procjenu mjera za ublažavanje klimatskih promjena te za modeliranje potrošnje energije, energetske transformacije i ekstrakciju resursa. Može biti korišten za obračun energetskih i ne-energetskih emisija i odliva stakleničkih plinova u svim sektorima gospodarstva. Dodatno, može biti korišten za analizu lokalnih i regionalnih emisija onečišćujućih tvari što ga čini pogodnim za studije koje uključuju modeliranje klimatskih i okolišnih među-utjecaja. S obzirom na njegovu transparentnost i prilagodljivost, mnogi proračuni mogu biti izrađeni $u$ okviru njegovih mogućnosti (Heaps, 2016).

Za modeliranje neposredne potrošnje energije korišteni su detaljni sektorski modeli s pristupom odozdo-prema-gore na temelju kojih je moguće simulirati utjecaje mjera energetske učinkovitosti (Pukšec, Vad Mathiesen, \& Duić, Potentials for energy savings and long term energy demand of Croatian households sector, 2013) (Pukšec, Krajačić, Lulić, Vad Mathiesen, \& Duić, 2013) (Irsag, Pukšec, \& Duić, 2012) te su kalibrirani s potrošnjom na 2014. godinu. Rezultati modeliranja energetske potrošnje korišteni su kao ulazni podaci za analizu energetskih transformacija. Dodatno, modeliranje je uključilo i međuovisnost potražnje o proizvodnji energije iz varijabilnih obnovljivih izvora energije, ovo se prvenstveno odnosi na simulacije naprednog korištenja baterija električnih vozila za optimiranje rada elektroenergetskog i prometnog sustava te na korištenje električnih kotlova sa spremnicima topline za optimiranje rada elektroenergetskog toplinskog sustava.

Za planiranje elektroenergetskog sustava i analize uključivanja obnovljivih izvora energije, korišten je optimizacijski model Plexos (Energy Exemplar , 2016) (Tomšić, Rajšl, \& Filipović, 2018), s satnom rezolucijom te su simulacije provedene sve do 2050. godine. Dodatno, proveden je i paralelan kontrolni proračun elektroenergetskog sustava sekvencijalnim vremenskim modelom EnergyPLAN (Lund, 2015). 
Svi parametri u sektoru energetskih transformacija povezani su s obračunom potrošnje resursa i energije.

Rezultati su integrirani u cjeloviti višesektorski model NUSPCRO s mogućnošću izračuna integriranih klimatsko-energetskih projekcija te implikacija na izravne troškove i koristi kao i neizravne troškove i koristi u vidu emisije onečišćujućih tvari i utjecaja na zapošljavanje.

\section{Ulazni podaci}

U 1. tablici dan je prikaz ključnih izvora ulaznih podataka te mogućnosti izračuna utjecaja niskougljičnog razvoja modela NUSPCRO.

Tablica 1. Ključni ulazni podaci i izvori podataka

\begin{tabular}{|c|c|c|}
\hline Sektor & Podaci & Ključni izvori podataka \\
\hline $\begin{array}{l}\text { Makro-ekonomski i } \\
\text { demografski podaci }\end{array}$ & $\begin{array}{l}\text { Broj stanovnika, tečaj, BDP, stope } \\
\text { rasta BDP-a, bruto dodane vrijednosti } \\
\text { po industrijskim granama, stope } \\
\text { rasta bruto dodanih vrijednosti po } \\
\text { industrijskim granama }\end{array}$ & $\begin{array}{l}\text { (Capros, i dr., 2016). } \\
\text { (ODYSSEE-MURE, 2016). } \\
\text { (Državni zavod za statistiku, } \\
\text { 2015). }\end{array}$ \\
\hline $\begin{array}{l}\text { Analiza potrošnje } \\
\text { energije }\end{array}$ & $\begin{array}{l}\text { Potrošnja energije po sektorima } \\
\text { kućanstva, usluga, industrije, prometa, } \\
\text { poljoprivrede / šumarstva / ribarstva } \\
\text { po granama, karakteristike tehnologija } \\
\text { za potrošnju energije, penetracija } \\
\text { mjera energetske učinkovitosti i } \\
\text { razvoja tehnologija, utjecaj promjena } \\
\text { u ponašanju stanovnika, dijagram } \\
\text { opterećenja električne energije, } \\
\text { dijagram potrošnje topline, dijagram } \\
\text { korištenja vozila }\end{array}$ & $\begin{array}{l}\text { (Simones, Nijs, \& Ruiz, 2013). } \\
\text { (Pukšec, Krajačić, Lulić, Vad } \\
\text { Mathiesen, \& Duić, 2013). } \\
\text { (Pukšec, Vad Mathiesen, \& } \\
\text { Duić, Potentials for energy } \\
\text { savings and long term } \\
\text { energy demand of Croatian } \\
\text { households sector, 2013). } \\
\text { (Irsag, Pukšec, \& Duić, 2012). } \\
\text { (Vuk, Karan, \& Fabek, 2016). } \\
\text { (Državni zavod za statistiku, } \\
\text { 2015). } \\
\text { (ODYSSEE-MURE, 2016). }\end{array}$ \\
\hline $\begin{array}{l}\text { Analiza energetskih } \\
\text { transformacija }\end{array}$ & $\begin{array}{l}\text { Karakteristike postrojenja za energetske } \\
\text { transformacije: elektrane, toplane, } \\
\text { kotlovnice, rafinerije, postrojenja } \\
\text { za proizvodnju biogoriva itd., što } \\
\text { uključuje tehničke karakteristike, } \\
\text { način rada, cijene, troškove, projekcije } \\
\text { cijena, ograničenja, učinkovitosti, } \\
\text { ulazna goriva itd. }\end{array}$ & $\begin{array}{l}\text { (Simones, Nijs, \& Ruiz, 2013). } \\
\text { (Capros, i dr., 2016). } \\
\text { (ODYSSEE-MURE, 2016). } \\
\text { (Vuk, Karan, \& Fabek, 2016). } \\
\text { (HEP d.d., 2016). } \\
\text { (Black and Veatch, 2012). } \\
\text { (Vartiainen, Mason, \& Breyer, } \\
\text { 2015). }\end{array}$ \\
\hline
\end{tabular}


Lin Herenčić, Vladimir Jelavić i Valentina Delija-Ružić: Procjene utjecaja scenarija niskougljičnog razvoja RH Radovi Zavoda za znanstveni rad HAZU Varaždin; br. 29, 2018., str. 361-380

\begin{tabular}{|c|c|c|}
\hline Sektor & Podaci & Ključni izvori podataka \\
\hline Analiza resursa & $\begin{array}{l}\text { Cijene pojedinih vrsta energije, podaci } \\
\text { o zalihama resursa, pretpostavke } \\
\text { o novim nalazištima i proizvodnji, } \\
\text { potencijali za korištenje obnovljivih } \\
\text { izvora energije }\end{array}$ & $\begin{array}{l}\text { (Vuk, Karan, \& Fabek, 2016). } \\
\text { (Državni zavod za statistiku, } \\
\text { 2015). } \\
\text { (Agencija za ugljikovodike, } \\
\text { 2016). } \\
\text { (Capros, i dr., 2016). }\end{array}$ \\
\hline $\begin{array}{l}\text { Analiza utjecaja na } \\
\text { emisije stakleničkih } \\
\text { plinova i } \\
\text { onečišćujućih tvari }\end{array}$ & $\begin{array}{l}\text { Emisijski faktori za stakleničke plinove } \\
\mathrm{CO}_{2^{\prime}} \mathrm{CH}_{4^{\prime}} \mathrm{N}_{2} \mathrm{O} \text {, emisijski faktori za } \\
\text { onečišćcujuće tvari } \mathrm{NMHOS}, \mathrm{SO}_{2}, \mathrm{NO}_{x^{\prime}} \\
\mathrm{NH}_{3^{\prime}} \mathrm{PM}_{2,5^{\prime}} \mathrm{PM}_{10}\end{array}$ & $\begin{array}{l}\text { (Eggleston, Buendia, Miwa, } \\
\text { Ngara, \& Tanabe, 2006). } \\
\text { (Croatian Agenecy for } \\
\text { Environment and Nature, } \\
\text { 2016). } \\
\text { ( European Environment } \\
\text { Agency, 2016). } \\
\text { (Croatian Agenecy for } \\
\text { Environment and Nature, } \\
\text { 2016). }\end{array}$ \\
\hline $\begin{array}{l}\text { Analiza utjecaja na } \\
\text { zapošljavanje }\end{array}$ & $\begin{array}{l}\text { Broj zaposlenih po jedinici instalirane } \\
\text { snage, proizvodnje, investicije ili druge } \\
\text { aktivnosti }\end{array}$ & $\begin{array}{l}\text { (IRENA, 2016). } \\
\text { (Cambridge Econometrics et } \\
\text { al., 2015). } \\
\text { (ECORYS, 2012). } \\
\text { (Rutovitz \& Harris, 2012). } \\
\text { (Environment and Energy Study } \\
\text { Institute, 2015). } \\
\text { (Bacon \& Kojima, 2011). }\end{array}$ \\
\hline $\begin{array}{l}\text { Analiza izravnih i } \\
\text { neizravnih troškova } \\
\text { i koristi }\end{array}$ & $\begin{array}{l}\text { Jedinični troškovi tehnologija, } \\
\text { kapitalni troškovi, troškovi za } \\
\text { pogon i održavanje, trošak kapitala, } \\
\text { eksterni troškovi emisija, troškovi } \\
\text { nezaposlenosti }\end{array}$ & $\begin{array}{l}\text { (Simones, Nijs, \& Ruiz, 2013). } \\
\text { (HEP d.d., 2016). } \\
\text { (Black and Veatch, 2012). } \\
\text { (Vartiainen, Mason, \& Breyer, } \\
\text { 2015). } \\
\text { ( European Environment } \\
\text { Agency, 2014). } \\
\text { (Gerard, Vasamis, \& Van der } \\
\text { Beken, 2012). } \\
\end{array}$ \\
\hline
\end{tabular}

\section{Proces izrade scenarija}

S obzirom na više korištenih softverskih alata te opsežnost modeliranja, proces izrade scenarija i analiza rezultata je iterativan. Na slici 1 prikazan je proces izrade scenarija. 


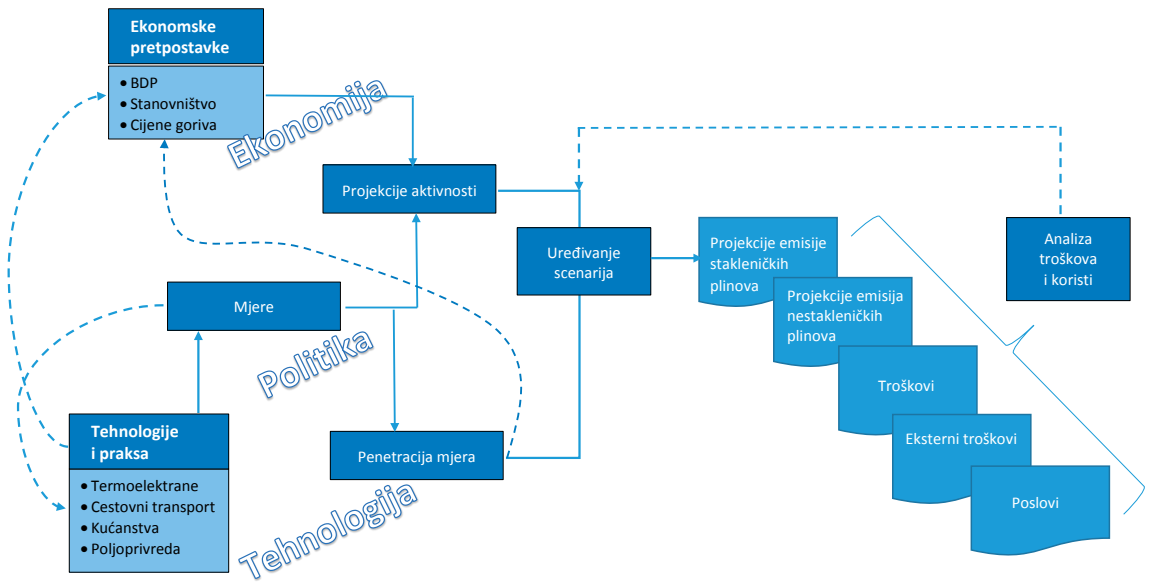

Slika 1. Proces izrade scenarija u modelu NUSPCRO

Scenariji se izrađuju na temelju velikog broja ulaznih podataka te metodologija za proračun utjecaja. Pritom se modeliraju utjecaji ekonomije, politika i mjera te tehnologija i promjena u ponašanju stanovnika. Ovisno o ciljevima koji se žele analizirati, rezultati u određenim scenarijima mogu biti pokazatelj potrebe za simulacijom dodanih mjera kako bi se ostvarili zadani ciljevi za smanjenje emisija ili ispitala optimalna kombinacija mjera za smanjenje emisija. Dodatnim iteracijama ispituje se osjetljivost na promjene u parametrima.

Kao rezultat proizlaze projekcije emisija stakleničkih plinova, projekcije emisija nestakleničkih plinova, troškovi, eksterni troškovi te utjecaj na zapošljavanje koji se potom mogu evaluirati na monetarnoj osnovi kako bi se dobila integrirana analiza troškova i koristi. Konzistentni odnosi i korištene metodologije omogućavaju dosljednu usporedivost scenarija ta procjenu graničnih utjecaja pojedinih politika i mjera.

\section{Scenariji}

Prilikom izrade procjene utjecaja politike i mjera na razini Europske unije, često se analizira niz scenarija s različitim parametrima (European Commission, 2014). Jednakim pristupom, prilikom izrade stručnih podloga Strategiju niskougljičnog razvoja Republike Hrvatske do 2030. godine s pogledom na 2050. go- 
dinu, analizirano je niz scenarija, a kao reprezentativni izabrana su tri: Referentni scenarij (NUR), Scenarij postupne tranzicije (NU1), Scenarij snažne tranzicije (NU2), što je prikazano na slici 3.

Referentni scenarij NUR predstavlja nastavak postojeće prakse, u skladu s važećom regulativom i prihvaćenim ciljevima do 2020. godine. Ovaj scenarij pretpostavlja tehnološki napredak i rast udjela obnovljivih izvora energije i energetske učinkovitosti temeljem tržišne situacije i danas utvrđenih ciljnih energetskih standarda. U ovom scenariju pretpostavlja se da će cijena $\mathrm{CO} 2$ vrlo malo rasti, nedostatno da predstavlja pokretač za promjene. Emisije u ovom scenariju ostaju otprilike na razini današnjeg stanja, s time što bi se u razdoblju nakon 2040. godine mogle i povećavati. Ovaj scenarij ne vodi niskougljičnom gospodarstvu.

Scenarij postupne tranzicije NU1 dimenzioniran je tako da se sigurno ispune ciljevi smanjenja emisije koje bi mogli biti obveza u okviru interne sheme obveza EU i s tim u vezi ciljevi međunarodnog dugoročnog dogovora da se porast temperature održi unutar $2^{\circ} \mathrm{C}$, a po mogućnosti i unutar $1,5^{\circ} \mathrm{C}$. U ovom scenariju smanjenje emisije se postiže primjenom niza troškovno učinkovitih mjera, snažnim poticanjem energetske učinkovitosti i primjeni obnovljivih izvora energije koji bi, u proizvodnji električne energije, nakon 2030. godine mogli velikim dijelom biti potpuno tržišno konkurentni. Scenarij pretpostavlja snažan rast cijena $\mathrm{CO}_{2}$, do $90 \mathrm{EUR} / \mathrm{t} \mathrm{CO}$ u 2050. godini (Capros, i dr., 2016), što je glavni pokretač tranzicije.

Scenarij snažne tranzicije NU2 dimenzioniran je s ciljem da se u 2050. godini postigne smanjenje emisije $80 \%$ u odnosu na 1990. godinu (European Commission, 2011). To je ciljno smanjenje koje je inače postavljeno kao zajednički cilj EU. U ovom scenariju kao i u NU1 pretpostavlja se snažan porast cijena $\mathrm{CO}_{2}$ do 90 EUR/t $\mathrm{CO}_{2}$ u 2050. godini (Capros, i dr., 2016) te vrlo snažne mjere energetske učinkovitosti.

\section{REZULTATI}

Opis smjernica dostupan je u Nacrtu Strategije niskougljičnog razvoja Republike Hrvatske do 2030. godine s pogledom na 2050. godinu (Ministarstvo zaštite okoliša i energetike, 2017). U nastavku je dan pregled procjene utjecaja provedbe smjernica na ključne energetske, okolišne, socijalne i gospodarske pokazatelje te je napravljena analiza troškova i koristi. 


\section{Pokazatelji utjecaja na energetiku}

Na slikama 2-7 nalazi se pregled izabranih energetskih pokazatelja po scenarijima i godinama.

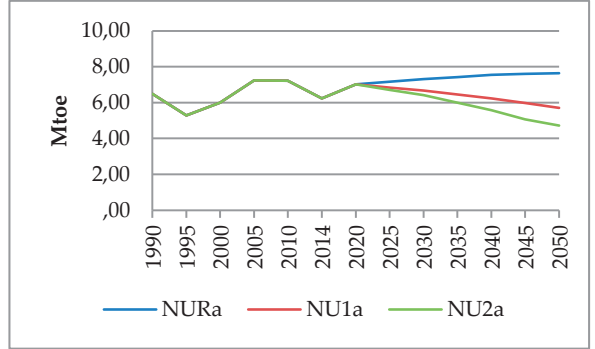

Slika 2. Neposredna potrošnja energije po scenarijima i godinama

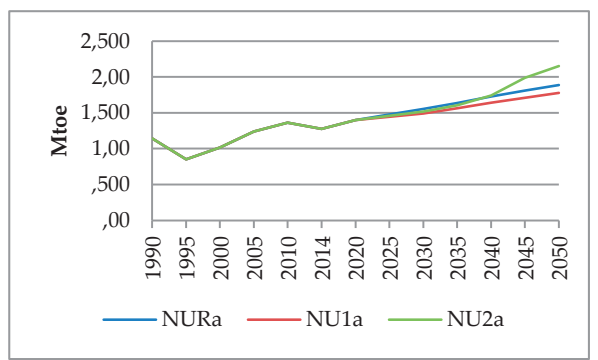

Slika 3. Neposredna potrošnja električne energije po scenarijima i godinama

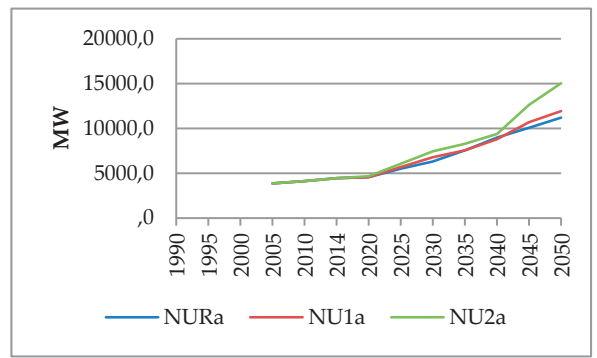

Slika 4. Instalirana snaga elektrana

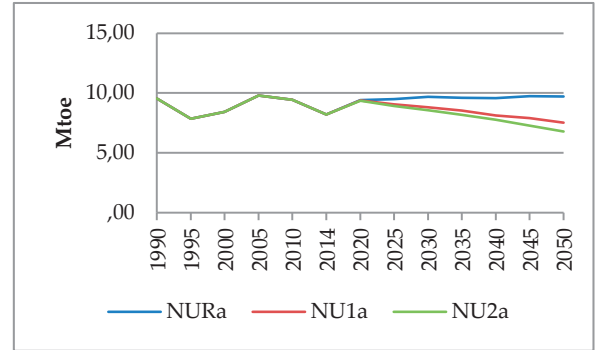

Slika 5. Ukupna potrošnja energije po scenarijima i godinama

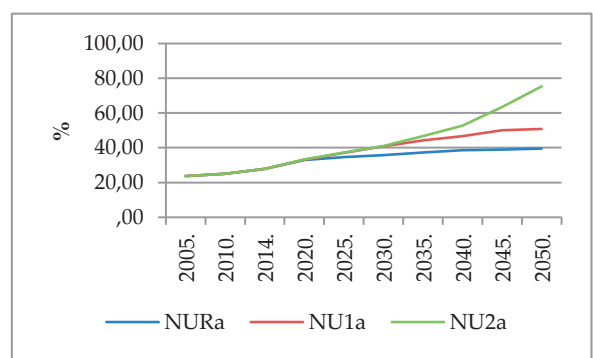

Slika 6. Udio obnovljivih izvora energije u bruto neposrednoj potrošnji energije

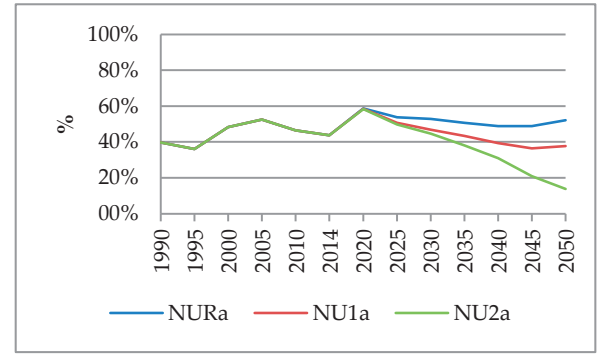

Slika 7. Ovisnost o uvozu energije 
Vidljivo je kako je procijenjeno da postoji značajan potencijal za uštede energije u neposrednoj potrošnji u niskougljičnim scenarijima u odnosu na Referentni scenarij, prvenstveno u sektoru kućanstva i usluga te u prometu. Niskougljičnim razvojem neposredna potrošnja energije može biti do $12 \%$ niža u 2030. godini, a u 2050. godini do 38\% niža u odnosu na NUR scenarij. Unatoč tome, očekuje se rast neposredne potrošnje električne energije, prvenstveno dio mjera za smanjenje emisija stakleničkih plinova u prometu i ostalim sektorima.

S obzirom na manji faktor opterećenja elektrana na obnovljive izvore u odnosu na konvencionalne elektrane te zbog rasta potrošnje električne energije, biti će potreban snažan rast instaliranih kapaciteta za proizvodnju električne energije, koji bi se do 2050. godine mogli i utrostručiti u odnosu na 2014. godinu. Pritom niskougljičnim razvojem može doći do ušteda ukupne (primarne) potrošnje energije od 30\% u odnosu na Referentni scenarij u 2050. godini.

Udio obnovljivih izvora u NUR scenariju je 35,7\% u 2030. godini, dakle iznad cilja EU za 2030. godinu (27\%). Udio obnovljivih izvora energije u 2030. godini po NU1 scenariju je 40,8\%, u 2050. godini mogao bi biti 50,9\%. Ukupni udio obnovljivih izvora energije u NU2 scenariju u 2030. godini iznosi 41,0\%, a u 2050. godini preko $70 \%$. Razvojem obnovljivih izvora energije, sustava za skladištenje energije te naprednom integracijom elektroenergetskog sustava s prometom i toplinarstvom moguće je gotovo u potpunosti dekarbonizirati proizvodnju električne energije te doprinijeti snažnom smanjenju emisija u ostalim sektorima.

Svi navedeni faktori mogu utjecati na smanjenje ovisnosti o uvozu energije te time na rast energetske sigurnosti. Naime, razvojem po NUR scenariju, ovisnost o uvozu energije prešla bi preko $50 \%$, a daljnji rast ovisio bi o uspješnosti u nalaženju i eksploataciji novih nalazišta nafte i plina.

\section{Pokazatelji utjecaja na okoliš}

Na slici 8 prikazani su pokazatelji emisija stakleničkih plinova po sektorima i po scenarijima. 


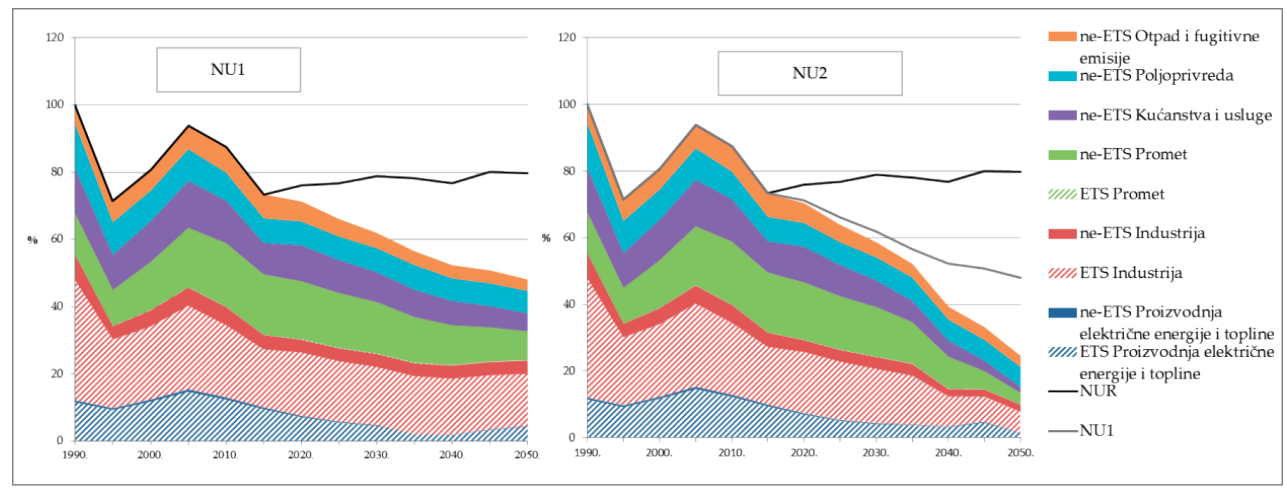

Slika 8. Emisije stakleničkih plinova po sektorima u niskougljičnim scenarijima

Smanjenje emisija stakleničkih plinova jedan je od osnovnih ciljeva niskugljičnog razvoja. Emisije u NUR scenariju ostaju otprilike na razini današnjeg stanja, s time što bi se u razdoblju nakon 2040. godine mogle i povećavati. NU1 scenarijem smanjuje se emisija stakleničkih plinova za 38\% u 2030. godini i 52\% u 2050. godini, u odnosu na 1990. godinu. Scenarij NU2 postavlja cilj smanjenja od $80 \%$ u 2050. godini u odnosu na 1990. godinu. U ovom scenariju, u 2050. godini, dominantni izvor emisije ostaje promet, zatim poljoprivreda, industrija i fugitivna emisija. Primjenom danas poznatih mjera, onih koje su u socio-gospodarskom pogledu prihvatljive za poljoprivredu, moglo bi se postići smanjenje emisije od $77 \%$. Ostatak do $80 \%$ računa se na nove, danas nepoznate tehnologije.

Dodatno, rezultati su pokazali i pozitivan utjecaj na smanjenja emisija onečišćujućih tvari u zrak SO2, NOX, NH3, sitnih čestica PM2,5 i PM10 te HOS, poglavito u gradovima. Proračuni pokazuju da se prelaskom na niskougljične scenarije postižu manje emisije 9 do $32 \%$ u 2030. godini te 27 do $42 \%$ u 2050. godini u odnosu na referentni scenarij za navedene tvari. Navedeno doprinosi i ispunjenju obveza Republike Hrvatske o smanjenju navedenih onečišćujućih tvari prema protokolima Konvencije o daljinskom prekograničnom onečišćenju zraka i Europske Direktive 2016/2284.

S druge strane, neke od mjera predstavljaju potencijalnu prijetnju za pojedine sastavnice okoliša i prirodu. Neki od primjera su: korištenje obnovljivih izvora energije za proizvodnju električne energije i/ili topline i izgradnja kogeneracijskih postrojenja, trajno skladištenje ugljikovog dioksida, korištenje biogoriva $u$ prijevozu, uvođenje novih poljoprivrednih kultura, uključivo i sadnju energetskih usjeva i dr. 


\section{Pokazatelji utjecaja na društvo}

Sociološki utjecaj se primarno odnosi na zapošljavanje, pozitivni utjecaj javnih prihoda koji se ostvaruju naknadama na emisije CO2 te na opterećenje kućnog proračuna zbog troškova energije i novih naknada na emisiju CO2. Koristi po društvo su izbjegnuti štetni učinci na zdravlje zbog smanjene emisije SO2, NOx i čestica.

Kao ključni pokazatelj određen je utjecaj na broj izravnih radnih mjesta. $\mathrm{Na}$ slici 9 prikazan je utjecaj na broj radnih mjesta u NU1 scenariju u odnosu na NUR sceanrij.

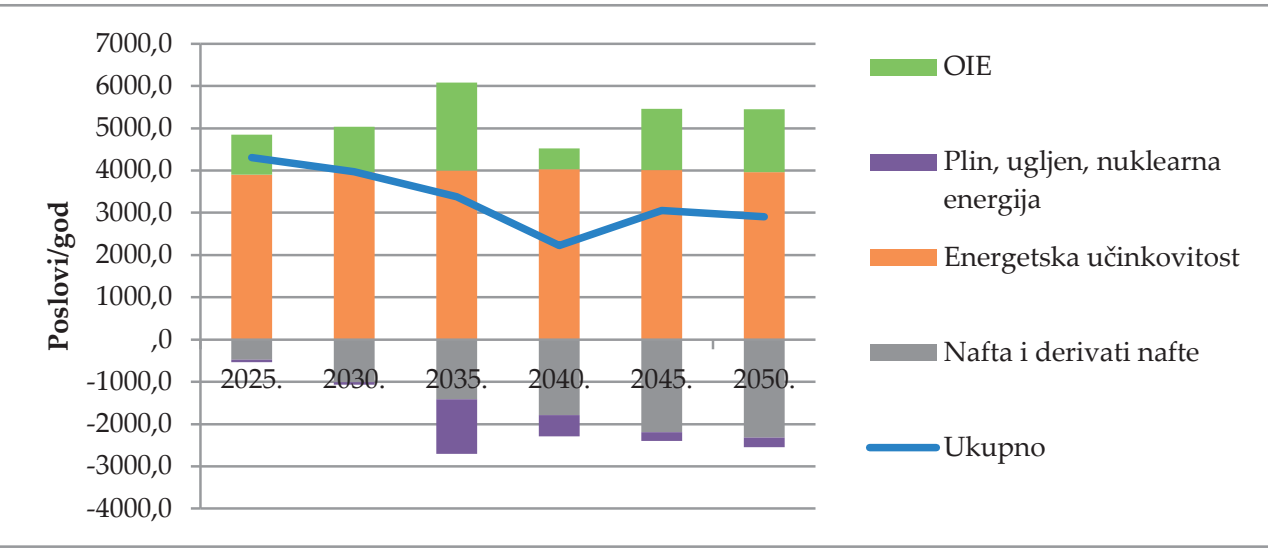

Slika 9. Razlika broja radnih mjesta u NU1 scenariju u odnosu na NUR scenarij

Najveći potencijal za nova radna mjesta nalazi u primjeni mjera energetske učinkovitosti, prvenstveno u zgradarstvu te zatim u razvoju obnovljivih izvora energije. Utjecaj smanjenja radnih mjesta neće biti značajan u razdoblju do 2030. godine, s obzirom da se razina aktivnosti u sektoru istraživanja i eksploatacija nafte i plina ne mijenja značajno. Međutim, u razdoblju nakon 2030. godine, s obzirom na sve manje potrebe za fosilnim gorivima i neizvjesnosti o novim nalazištima nafte i plina, moguće je veće smanjenje poslova u ovom sektoru. Ukupno, tranzicija prema niskougljičnom gospodarstvu, mogla bi kumulativno stvoriti 50.000 (NU1) do 80.000 (NU2) radnih mjesta do 2030. godine, tj. u prosjeku 5.000 do 8.000 poslova godišnje u odnosu na referentni scenarij u razdoblju od 2021. do 2030. godine. 


\section{Pokazatelji utjecaja na gospodarstvo}

Nastavak razvoja po Referentnom scenariju doveo bi do velikih ekonomskih izazova. Republika Hrvatska je u 2014. godini, uz dobru hidrologiju, blagu zimu, te relativno niske cijene uvoza bila neto uvoznik energije $u$ visini od oko 2,3 mlrd. EUR (World Bank, 2016), odnosno 5,2\% BDP-a. S obzirom na ograničene nacionalne resurse, s razvojem prema NUR scenariju, neto uvoz energije bi porastao na oko 3,6 mlrd. EUR do 2020. godine (7,4\% BDP-a), 4,2 mlrd. EUR do 2030. godine (7,6\% BDP-a) te na oko 4,4 mlrd. EUR 2050. godine (5,5\% BDP-a). Dodatno, bila bi potrebna značajna ulaganja u prateću infrastrukturu za fosilna goriva. NUR scenarijem došlo bi tek do blagog pada energetske potrošnje u zgradarstvu te energetske intenzivnosti u industriji. Na taj način ne bi došlo do uštede na energetskim računima za građane, tj. sredstva ne bi mogla biti uložena $u$ druge sektore, a energetski intenzivna industrija imala bi poteškoće $u$ razvoju konkurentnosti. Bez aktivnog ulaganja u istraživanje, razvoj i korištenje novih tehnologija za smanjenje emisija stakleničkih plinova propustila bi se prilika za razvoj industrijskih grana i podizanje konkurentnosti gospodarstva.

Utjecaj razvoja po scenarijima NU1 i NU2 na gospodarstvo očituje se kroz složene strukturne promjene. S pozitivne strane, rastu ekonomska aktivnost, zaposlenost i inovacije u sektorima koji proizvode čistu energiju, ulažu u energetsku učinkovitost, kao i u dijelovima gospodarstva koji će aktivno sudjelovati u održivom gospodarenju otpadom i kružnoj ekonomiji. S time su povezane i značajne dugoročne investicije koje imaju i multiplikativne učinke. S negativne strane, dolazi do određenog rasta troškova energije is time povezanog pada gospodarske aktivnosti te postupno dolazi do manje zaposlenosti u sektorima i aktivnostima koji koriste tradicionalne tehnologije zasnovane na fosilnim gorivima. Važno je uzeti u obzir da Republika Hrvatska ostvaruje značajna financijska sredstva od europskih strukturnih i investicijskih fondova te mehanizama u okviru ETS-a. Općenito, prihodi koje može ostvariti RH iz EU fondova nadmašuju davanja za proračun EU. Svi ovi prihodi pomažu gospodarskom rastu bez potrebe za rastom zaduženosti, a sredstva se ulažu u održive projekte koji vraćaju uložene investicije.

Niskougljičnim razvojem $u$ energetskom sustavu težište troškova se premješta s troškova za nabavu goriva na investicijske troškove. Bit će potrebne kontinuirane investicije kako bi se u dužem roku ostvario troškovno učinkovit niskougljični razvoj. Investicije se prvenstveno moraju pokrenuti u sektorima neposredne potrošnje energije - kućanstvima, uslugama, prometu i industriji. Potrebna ulaganja za obnovu zgrada do 2050. godine iznose od 70 do 100 mlrd. EUR. S obzirom na razvoj konkurentnosti OIE, te utjecaj mjera u neposrednoj po- 
trošnji na manju potražnju, troškovi u sektoru energetskih transformacija mogu biti i manji nego u Referentnom scenariju (NU1 scenarij) jer dolazi do ušteda $u$ sektoru nafte i plina (značajnije nakon 2030. godine) te manje potrošnje električne energije, ali mogu biti i značajno veći u slučaju snažne elektrifikacije u sektoru prometa i veće potrošnje električne energije (NU2 scenarij). U odnosu na stanje u 2014. godini očekuje se rast niveliranih proizvodnih troškova proizvodnje električne energije za oko $20 \%$ do 2020. godine i u NUR scenariju. Do 2030. godine niskougljičnim razvojem nivelirani trošak proizvodnje mogao bi porasti za dodatnih 5 do $11 \%$ te se nakon toga smanjivati. Cijene za krajnje kupce ovisit će i o troškovima za prijenos i distribuciju, poreznoj politici te ostalim troškovima, npr. financiranju mjera EnU u neposrednoj potrošnji.

Održivim gospodarenjem otpadom i kružnim gospodarstvom dolazi do ušteda sirovina, a niskougljičnim razvojem otvaraju se nove tržišne niše. Uključivanje domaće industrije u nova razvojna područja u prilika je za razvoj inovacija, konkurentnosti i industrijski razvoj koji može biti snažan generator rasta BDP-a i zaposlenosti. Globalno, u analizi niskougljičnih tehnologija s najvećim očekivanim rastom istaknuti su sunčani fotonaponski sustavi, vjetroelektrane, hibridna i električna vozila te LED rasvjeta (Goldman Sachs, 2015).

Do 2030. godine biti će potrebno ostvariti investicije veće za 4 do $6 \mathrm{mlrd}$. EUR do 2030. godine od investicija koje bi bile u Referentom scenariju, istovremeno će se ostvariti ušteda na uvozu energije, materijala te troškova za emisijske jedinice u ETS-u u visini od 3 do 4 mlrd. EUR u odnosu na Referentni scenarij. Popratne koristi u vidu pozitivnih utjecaja manjeg onečišćenja zraka te otvaranja novih radnih mjesta mogu imati značajan pozitivan utjecaj vrijedan od 1,5 do gotovo 2,5 mlrd.

\section{Analiza troškova i koristi}

Za oba scenarija NU1 i NU2 postiže se ukupna neto korist za društvo. Korist, koju čine izbjegnuti troškovi zbog ušteda u gorivu, ušteda u materijalima i smanjena davanja za jedince $\mathrm{CO}_{2}$, te indirektne koristi zbog izbjegnutog onečišćenja zraka i novih radnih mjesta, su veće od troškova.

Pritom procjena ne obuhvaća izbjegnute štete u okolišu zbog utjecaja klimatskih promjena, s obzirom da takve procjene još nisu raspoložive. Međutim, zaključci globalnih studija upućuju na to da su troškovi ublažavanja znatno manji od šteta koje su uzrokovane promjenom klime (Stern, 2006).

Na godišnjoj razini do 2030. godine, potrebno je ostvariti dodatne investicije u prosjeku u visini od oko 1,0\% (NU1) do 1,5\% (NU2) kumulativnog BDP-a, od čega će se 65 do $75 \%$ vratiti kroz uštede na uvozu goriva i materijala, a popratne koristi biti će u visini od 0,3 do 0,5\% BDP-a. 


\section{DISKUSIJA}

Ovim radom dan je doprinos cjelovitom i međusektorskom planiranju i procjeni utjecaja klimatsko-energetskog razvoja Republike Hrvatske. Korišteno je više softverskih paketa i kombinirane su metode optimizacije i simulacije kako bi se razvio integralni model NUSPCRO.

Pokazano je da procjene odgovaraju procjenama provedenim od strane Europske komisije. Međutim, Republika Hrvatska, s obzirom na niži BDP po stanovniku, može odabrati put scenarija postupne tranzicije čime se optimiranju potrebni dodatni napori do 2030. godine i primjenjuju troškovno učinkovite mjere s bržim povratom ulaganja. Uz odgovarajuće okolnosti Republika Hrvatska može povećati ambiciju te krenuti putem scenarija snažne tranzicije.

S obzirom na široke implikacije prilikom planiranja i izrade klimatsko-energetske politike i mjera važno je raditi procjene utjecaja i optimirani politiku i mjere s obzirom na nacionalne osobitosti i okolnosti. Kao moguće nastavno istraživanje kojim bi se dodatno doprinijelo detaljnosti i kvaliteti procjena utjecaja moguće je ukazati na istraživanje ponašanja potrošača i integriranje istoga u modele za procjenu utjecaja klimatsko-energetske politike i mjera.

\section{LITERATURA}

1. European Environment Agency. (2014). Costs of air pollution from European industrial facilities 2008-2012 - an updated assessment. European Environment Agency.

2. European Environment Agency. (2016). EMEP/EEA air pollutant emission inventory guidebook 2016, Technical guidance to prepare national emission inventories, Long range Transboundary Air Pollution. European Environment Agency.

3. Agencija za ugljikovodike. (2016). Podaci dostavljeni za potrebe projekta. Agencija za ugljikovodike.

4. R. BACON \& M. KOJIMA (2011). Issues in estimating the employment generated by energy sector activities. The World Bank, Sustainable Energy Department.

5. Black and Veatch. (2012). Cost and Performance Data for Power Generation Technologies. National Renewable Energy Laboratory.

6. C. BÖHRINGER, A. KELLER, M. BORTOLAMEDI, \& A. SEYFFARTH (2016). Good things do not always come in threes: On the excess cost of overlapping regulation in EU climate policy. Energy Policy, 94, 502-508. 
Lin Herenčić, Vladimir Jelavić i Valentina Delija-Ružić: Procjene utjecaja scenarija niskougljičnog razvoja RH Radovi Zavoda za znanstveni rad HAZU Varaždin; br. 29, 2018., str. 361-380

7. M. BOŽIČEVIĆ, Ž. VRHOVČAK Tomšić, \& N. DEBRECIN, (2006). Potential and use of renewable energy sources in Croatia. Renewable Energy, 31(12), 1867-1872.

8. Cambridge Econometrics et al. (2015). Assessing the Employment and Social Impact of Energy Efficiency, Final report, Volume 1: Main report. Cambridge Econometrics, E3M-lab, Warwick Institute for Employment Research, ICF International.

9. P. CAPROS, A. DE VITA, L. PAROUSSOS, P. FRAGKOS, HÖGLUND-ISAKSSON, L., S, F., \& WITZKE, H. P. (2016). EU Reference Scenario 2016 Energy, transport and GHG emissions Trends to 2050. European Commission.

10. M. CARVALHO, (2012). EU energy and climate change strategy. Energy, 40(1), 19-22.

11. P. CRIQUI, \& S. MIMA, (2012). European climate-energy security nexus: A model based scenario analysis. Energy Policy, 41, 827-842.

12. Croatian Agenecy for Environment and Nature. (2016). National Inventory Report 2016, Croatian greenhouse gas inventory for the period 1990-2014. Croatian Agenecy for Environment and Nature.

13. Croatian Agenecy for Environment and Nature. (2016). Republic Of Croatia 2016 Informative Inventory Report (1990 - 2014) under the Convention on Long-range Transboundary Air Pollution (CLRTAP). Croatian Agenecy for Environment and Nature.

14. de Parthius, C., \& Trotignon, R. (2014). Governance of CO2 markets: Lessons from the EU ETS. Energy Policy, 75, 100-106.

15. P. del Rio, (2017). Why does the combination of the European Union Emissions Trading Scheme and a renewable energy target makes economic sense? Renewable and Sustainable Energy Reviews, 74, 824-834.

16. Državni zavod za statistiku. (2015). Statistički ljetopis 2015. Državni zavod za statistiku.

17. ECORYS. (2012). The number of Jobs dependent on the Environment and Resource Efficiency improvements, Final Report. ECORYS.

18. H. EGGLESTON, L. BUENDIA, K. MIWA, T. NGARA, \& K. TANABE, (2006). 2006 IPCC Guidelines for National Greenhouse Gas Inventories, Prepared by the National Greenhouse Gas Inventories Programme. The Intergovernmental Panel on Climate Change (IPCC).

19. Energy Exemplar . (2016). Plexos. Energy Exemplar.

20. Environment and Energy Study Institute. (2015). Jobs in Renewable Energy and Energy Efficiency. Environment and Energy Study Institute.

21. European Commission. (2011). COM(2011) 112 final A Roadmap for moving to a competitive low carbon economy in 2050 . European Commission. 
22. European Commission. (2011). COM(2011) 144 final White Paper Roadmap to a Single European Transport Area - Towards a competitive and resource efficient transport system. Brussels: European Commission.

23. European Commission. (2014). COM(2014) 15 final A policy framework for climate and energy in the period from 2020 to 2030. Brussels: European Commission.

24. European Commission. (2014). SWD(2014) 15 final Impact assessment, Accompanying the document, A policy framework for climate ans energy in the period from 2020 up to 2030. European Commission.

25. European Commission. (2015). COM(2015) 337 final Proposal for a Directive amending Directive 2003/87/EC to enhance cost-effective emission reductions and low-carbon investments. Brussels: European Commission.

26. European Commission. (2016). COM(2016) 51 final An EU Strategy on Heating and Cooling. Brussels: European Commision.

27. European Commission. (2016). Commission proposes new rules for consumer centred clean energy transition. Preuzeto 18. 32018 iz https://ec.europa. eu/energy/en/news/commission-proposes-new-rules-consumer-centred-clean-energy-transition

28. F. FLUES, A. LÖSCHEL, B. LUTZ, \& O. SCHENKER, (2014). Designing an EU energy and climate policy portfolio for 2030: Implications of overlapping regulation under different levels of electricity demand. Energy Policy, 75, 91-99.

29. M. GERARD, D. VASAMIS, \& W. VAN DER BEKEN (2012). Why invest in employment? A study on the cost of unemployment, Final report. European Federation for Services to Individuals (EFSI).

30. Goldman Sachs. (2015). The Low Carbon Economy. Goldman Sachs.

31. F. GRACCEVA, \& P. ZENIEWSKI (2014). A systemic approach to assessing energy security in a low-carbon EU energy system. Applied Energy, 123, 335348.

32. C. HEAPS (2016). Long-range Energy Alternatives Planning System. Maine: Stockholm Environment Institute.

33. HEP d.d. (2016). Podaci dostavljeni za potrebe projekta. HEP d.d.

34. M. HOWELLS, H. ROGNER, N. STRACHAN, \& C. HEAPS, (2011). OSeMOSYS: The Open Source Energy Modeling System: An introduction to its ethos, structure and development. Energy Policy, 39(4), 5850-5870.

35. IPCC. (1990-2014). Climate Change 2014: Synthesis Report. Contribution of Working Groups I, II and III to the Fifth Assessment Report of the Intergovernmental Panel on Climate Change. Geneva: IPCC. Dohvaćeno iz IPCC Intergovernmental Panel on Climate Change. 
36. IRENA. (2016). Renewable Energy and Jobs. International Renewable Energy Agency.

37. IRENA. (2018). Renewable Energy Prospects for the European Union. Brusse1s: European Union and IRENA.

38. B. IRSAG, T. PUKŠEC, \& N. DUIĆ, (2012). Long term energy demand projection and potential for energy savings of Croatian tourism-catering trade sector. Energy, 48(1), 398-405.

39. B. KNOPF, Y. CHEN, \& De E. CIAN (2013). Beyond 2020 - strategies and costs for transforming the European energy system. Climate Chnage Economics, $4(1)$.

40. B. KNOPF, P. NAHMMACHER \& E. SCHMID (2015). The European renewable energy target for 2030 - An impact assessment of the electricity sector. Energy Policy, 85, 50-60.

41. I. KOMUŠANAC, B. ĆOSIĆ \& N. DUIĆ (2016). Impact of high penetration of wind and solar PV generation on the country power system load: The case study of Croatia. Applied Energy, 184, 1470-1482.

42. G. KRAJAČIĆ, N. DUIĆ, Z. ZMIJAREVIĆ, B. MATHIESEN, A. ANIĆ VUČINIĆ, \& M. CARVALHO, (2011). Planning for a 100\% independent energy system based on smart energy storage for integration of renewables and CO2 emissions reduction. Applied Thermal Engineering, 31(13), 2073-2083.

43. H. LUND (2015). EnergyPLAN. Sustainable Energy Planning Research Group, Aalborg University.

44. Ministarstvo zaštite okoliša i energetike. (2017). Strategija niskougljičnog razvoja Republike Hrvatske za razdoblje do 2030. godine s pogledom na 2050. godinu, Bijela knjiga, Nacrt. Ministarstvo zaštite okoliša i energetike.

45. ODYSSEE-MURE. (2016). ODYSSEE database. Preuzeto 2016 iz http://www. indicators.odyssee-mure.eu/energy-efficiency-database.html

46. P. G. PREBEG, G. KRAJACIC, \& N. DUIC, (2016). Long-term energy planning of Croatian power system using multi-objective optimization with focus on renewable energy and integration of electric vehicles. Applied Energy, 184, 1493-1507.

47. T. PUKŠEC, G. KRAJAČIĆ, Z. LULIĆ, B. VAD MATHIESEN \& N. DUIĆ (2013). Forecasting long-term energy demand of Croatian transport sector. Energy, 57, 169-176.

48. T. PUKŠEC, B. VAD MATHIESEN, \& N. DUIĆ, (2013). Potentials for energy savings and long term energy demand of Croatian households sector. Applied Energy, 101, 15-25.

49. J. RUTOVITZ \& S. HARRIS (2012). Calculating global energy sector jobs: 2012 methodolog. Greenpeace International by the Institute for Sustainable Futures, University of Technology Sydney. 
50. S. SIMONES, W. NIJS \& P. RUIZ (2013). The JRC-EU-TIMES model, Assessing the long-term role of the SET Plan Energy technologies. European Comission, Joint Research Centre.

51. N. STERN (2006). Stern Review on the Economics of Climate Change. HM Treasury.

52. Ž. TOMŠIĆ., I. RAJŠL \& I. FILIPOVIĆ (2018). Niskougljična strategije Republike Hrvatske za elektroenergetski sektor do 2050. godine. Zbornik odabranih radova 13. savjetovanja HRO CIGRE, 101-110.

53. E. VARTIAINEN, G. MASON \& C. BREYER (2015). PV LCOE in Europe 2015-2050. (str. 3024-3033). 31st European Photovoltaic Solar Energy Conference and Exhibition.

54. B. VUK, M. KARAN \& R. FABEK (2016). Energija u Hrvatskoj 2014. Ministarstvo gospodarstva Republike Hrvatske.

55. World Bank. (2016). Croatian Trade Summary 2014 Data. Preuzeto 2016 iz http://wits.worldbank.org/CountryProfile/en/Country/HRV/Year/2014/ Summary

\section{SAŽETAK \\ PROCJENE UTJECAJA SCENARIJA NISKOUGLJIČNOG RAZVOJA REPUBLIKE HRVATSKE}

Istraživanja vezana za klimatsko-energetsku politiku u Republici Hrvatskoj najčešće su vezana za pojedine segmente klimatsko-energetskog planiranja te je vidljiv je nedostatak međusektorskog i integrativnog planiranja klimatsko-energetskog razvoja. U ovom radu opisan je metodološki pristup i procjena ključnih utjecaja koji su izrađeni prilikom izrade stručnih podloga za Strategiju niskougljičnog razvoja Republike Hrvatske do 2030. godine s pogledom na 2050. godinu.

Rezultati su pokazali da će do 2030. godine biti potrebno ostvariti dodatna investicije u visini od oko 1,0 do 1,5\% BDP-a Republike Hrvatske. Istovremeno će se ostvariti ušteda na uvozu energije, materijala te troškova za emisijske jedinice u ETS-u u visini od 65 do 75\% vrijednosti dodatnih investicija, a pribrajanjem popratnih koristi u vidu pozitivnih utjecaja manjeg onečišćenja zraka te otvaranja novih radnih mjesta ukupne koristi niskougljičnog razvoja mogu nadići dodatne troškove. Ključni rezultati su se pokazali u skladu s onima dobivenim u Procjeni učinka Klimatsko-energetskog okvira do 2030. godine (European Commission, 2014).

Ključne riječi: niskougljični razvoj; održivi razvoj; klimatske promjene; obnovljivi izvori energije; energetska učinkovitost. 


\section{SUMMARY \\ IMPACT ASSESSMENT OF THE SCENARIOS FOR LOW-CARBON DEVELOPMENT OF THE REPUBLIC OF CROATIA}

Climate-related energy policy research in the Republic of Croatia is most often linked to certain climate-energy planning segments, and there is a lack of cross-sectoral and integrative climate-energy development planning. This paper describes the methodological approach and the assessment of the key impacts that have been estimated in the preparation of technical basis for the Low Carbon Development Strategy of Republic of Croatia until 2030 with a view to 2050.

The results showed that by 2030, additional investments would have to be made in the amount of about 1.0 to $1.5 \%$ of GDP of the Republic of Croatia. At the same time, savings will on the import of energy, materials and costs for emission units in the EU ETS will compensate around of 65 to $75 \%$ of the value of additional investments, and by adding the additional benefits in terms of positive impacts of lower air pollution and opening new jobs the total benefit of lowcarbon development can surpass the additional costs. Key results are in line with the Impact Assessment accompanying the 2030 Climate and Energy Framework (European Commission, 2014).

Key Words: low-carbon development; sustainable development; climate change; renewable energy sources; energy efficiency. 